\title{
STUDI FENOMENOLOGI: HARMONISASI PARADOKS WISATA RAKYAT SEBAGAI AKSELERATOR PENGENTASAN KEMISKINAN DI BALI
}

\author{
Putu Devi Rosalina \\ Email: putudevi31@gmail.com \\ SEKOLAH TINGGI PARIWISATA BALI INTERNASIONAL
}

\begin{abstract}
This study aims to (1) know the development of popular tourism industry in Bali; (2) know Bali's poverty alleviation program and its constraints; and (3) know the contribution of tourism in poverty alleviation. The research was done through observation data collection technique and literature study, by using populist qualitative tourism analysis. Based on the results of research and literature study, it can be concluded that the Government's poverty alleviation program is currently not very effective with the main focus of material assistance, whereas the most crucial is education and learning so that they can save themselves to get out of the poverty cycle. This is then the main reason for the emergence of the concept of populist tourism by focusing on how society itself becomes the subject of tourism. The basic foothold is that local people who are better informed of their area and through popular tourism can earn a living and reduce the leakage of funds, as well as their initiatives to further preserve the environmental and cultural conditions that are important assets of tourism.
\end{abstract}

Keywords: Tourism, Poverty Alleviation, Paradox, and Accelerator

\begin{abstract}
Abstrak
Penelitian ini bertujuan untuk (1) mengetahui perkembangan industri pariwisata populer di Bali; (2) mengetahui program pengentasan kemiskinan Bali dan kendala-kendalanya; dan (3) mengetahui kontribusi pariwisata dalam pengentasan kemiskinan. Penelitian ini dilakukan melalui teknik pengumpulan data observasi dan studi pustaka, dengan menggunakan analisis pariwisata kualitatif populis. Berdasarkan hasil penelitian dan studi literatur, dapat disimpulkan bahwa program pengentasan kemiskinan Pemerintah saat ini tidak terlalu efektif dengan fokus utama bantuan material, sedangkan yang paling penting adalah pendidikan dan pembelajaran sehingga masyarakat dapat menyelamatkan diri untuk keluar dari siklus kemiskinan. Inilah alasan utama munculnya konsep pariwisata kerakyatan dengan memusatkan perhatian pada bagaimana masyarakat itu sendiri menjadi subjek pariwisata. Pijakan dasar adalah bahwa orang-orang lokal yang mendapat informasi lebih baik
\end{abstract}


tentang daerah dan melalui pariwisata populer dapat mencari nafkah dan mengurangi kebocoran dana, serta inisiatif untuk lebih melestarikan kondisi lingkungan dan budaya yang merupakan aset penting pariwisata.

Kata Kunci: Pariwisata, Pengentasan Kemiskinan, Paradoks, dan Akselerator

\section{PENDAHULUAN}

Pariwisata telah menjadi industri terbesar di abad ini, hampir semua negara tertarik dan mengembangkan pariwisata sebagai salah satu sumber pendapatan devisa dan instrumen penting yang menggerakkan perekonomian, serta Indonesia, khususnya Bali. Provinsi Bali adalah provinsi kecil yang tidak memiliki sumber daya alam seperti beberapa daerah lain di Indonesia. Luas wilayah Bali hanya 0,29\% (5.632,86 km2) dari seluruh Indonesia dengan populasi lebih dari 5 juta orang. Pemerintah Provinsi Bali menetapkan tiga pembangunan, yaitu: Pertanian dalam arti luas, industri kecil dan kerajinan rumah tangga, dan pariwisata. Pemerintah berupaya menjadikan ketiga prioritas ini bergerak maju secara bersamaan untuk menjadi lokomotif pembangunan Bali. Namun faktanya sektor yang tumbuh paling cepat masih dominan oleh industri pariwisata.

Secara geografis dan demografis, tidak dapat disangkal bahwa Bali memiliki keindahan alam dan keragaman budaya. Keindahan alam dan keanekaragaman budaya yang unik ini kemudian menjadi daya tarik utama bagi orang luar untuk mengunjungi Bali. Pesatnya perkembangan pariwisata Bali membuat struktur ekonomi Bali menjadi sangat spesifik dan memiliki karakteristik tersendiri dibandingkan dengan provinsi lain di Indonesia. Ini mempertimbangkan ekonomi Bali yang dibangun dengan mengandalkan industri Pariwisata sebagai sektor terkemuka yang telah mampu mendorong perubahan dalam struktur ekonomi Bali. Perubahan dalam struktur ekonomi Bali juga terjadi ketika dilihat dari segi peluang kerja. Ternyata tren yang sedang terjadi adalah menurunnya pekerja yang 
bekerja di sektor pertanian dan sebaliknya semakin banyaknya pekerja di sektor jasa.

Pemerintah Provinsi Bali melihat peran pariwisata dalam pembangunan Bali sangat menentukan. Peran tersebut dapat dilihat dari kontribusi pariwisata terhadap Produk Domestik Regional Bruto (PDRB) dan penyerapan tenaga kerja. Peningkatan kunjungan turis ke Bali memiliki efek tidak langsung pada kontribusi sektor ini terhadap PDRB. Berdasarkan Statistik Pariwisata Bali oleh Kantor Dinas Pariwisata Bali (2013:5-35), meningkatnya jumlah kedatangan wisatawan asing (wisatawan) pada awal pelita pertama yang hanya 11.278 orang menjadi 170.505 pada akhir Pelita III, hingga saat ini telah mencapai 3.278.598 asing. wisatawan yang berkunjung ke Bali, serta pengeluaran sebesar US \$ 147,33 per hari untuk turis asing dan IDR. 494.000 untuk belanja wisatawan nasional Hal ini juga berkorelasi positif dengan peningkatan kontribusi untuk PDRB, yang didasarkan pada Data Bali Build (2013:335) kontribusi sektor Perdagangan, Hotel dan Restoran dari 9,52\% pada awal Pelita I (1969) menjadi 13, 90\% pada akhir Pelita III (1983) dan pada tahun 2013 sektor ini menyumbang 29,89\% dari PDB Bali.

Sayangnya, kontribusi pariwisata yang cepat tidak mampu memberikan kesejahteraan yang merata bagi masyarakat. Hal ini disebabkan disparitas distribusi pendapatan yang tidak berpihak pada kelas menengah ke bawah. Bukti paling mencolok terlihat dalam distribusi pendapatan antar kelompok. Berdasarkan Biro Pusat Statistik Bali, persentase pendapatan yang diterima oleh $40 \%$ dari penerima pendapatan terendah pada tahun 2013 adalah 16,32\%. Ini menunjukkan ketidakmerataan distribusi pada tingkat sedang, karena berdasarkan standar Bank Dunia, distribusi pendapatan dikatakan jika orang miskin menerima antara $12 \%-17 \%$. Namun demikian, jika dibandingkan dari tahun-tahun sebelumnya, Bali mengalami disparitas yang signifikan dalam 
penurunan. Diketahui bahwa pada tahun 2011 Bali mampu memposisikan diri dalam ketimpangan ringan, yaitu sebesar $17,20 \%$, serta dalam dua tahun terakhir, termasuk 22,14\% dan 20,75\% pada tahun 2009 dan 2010 masing-masing. Padahal, berdasarkan perkembangan pesat pariwisata, sebagai kontributor kontribusi terbesar, pada 2011 pengeluaran per orang per hari untuk wisatawan asing mencapai US \$ 154,87 atau meningkat $5,07 \%$. Demikian pula, pengeluaran per orang per hari untuk wisatawan domestik sebesar IDR 592.000 atau meningkat 17,7\%.

Secara awam, tampaknya menegaskan bahwa pariwisata tidak membantu mempercepat pengentasan kemiskinan atau dampaknya tidak cukup signifikan secara langsung terhadap pemerataan kesejahteraan. Jika dilihat secara global, para ahli benar-benar menaruh harapan besar pada pariwisata dalam upaya untuk mengurangi kemiskinan. Bahkan Bank Dunia pada tahun 2000 mulai meluncurkan istilah Pariwisata Berbasis Komunitas untuk mengundang komunitas lokal untuk berpartisipasi aktif dan menikmati hasilnya sendiri. Pariwisata populis adalah apa yang sejauh ini didengungkan sebagai penyelamat paradoksal antara pariwisata dan kemiskinan, sehingga diharapkan akan ada mutualisme simbiosis berkelanjutan antara keduanya.

Meskipun demikian, praktiknya tidak semudah teori wacana, masih banyak kebocoran dana dan pelanggaran aturan yang tidak berpihak pada penduduk setempat, dan hingga akhirnya rantai kemiskinan berputar kembali. Meskipun Hendrayana (2012) mengungkapkan itu harus diakui bahwa tingkat pengangguran di Bali relatif rendah (2,04\% pada Agustus 2012) bahkan yang terendah di Indonesia. Namun, ketimpangan pendapatan masih belum mencapai tingkat rendah, seperti yang terlihat dari Provinsi Bali 0,403 (BPS Provinsi Bali, 2013), yang untuk menyeimbangkan ketimpangan, Bali harus bekerja lebih keras untuk mencapai Rasio 0, dianggap efektif melalui pariwisata populer. Tetapi 
pemerintah belum percaya pada kekuatan masyarakat lokal dalam mengelola pariwisata secara berkelanjutan, termasuk mengurangi kemiskinan, yang Woodly dalam Pitana (2006:32-37) mengungkapkan bahwa partisipasi masyarakat lokal merupakan prasyarat untuk pariwisata berkelanjutan.

Untuk lebih lanjut mengungkapkan bagaimana paradoks fenomena ini dan mencari solusi untuk mengatasinya diperlukan analisis yang lebih mendalam melalui Teori Fenomenologi. Seperti yang diungkapkan oleh Schutz (1967:21-29) bahwa fenomenologi menguji bagaimana suatu objek benar-benar memiliki makna, dan interpretasi muncul melalui indera yang hanya sebagai media. Lebih lanjut, Schutz (1967:29-36) menekankan bahwa fenomenologi menjelaskan bagaimana seseorang membangun makna dari luar atau dari arus utama pengalaman melalui proses tipifikasi. Meskipun fenomenologi cenderung subjektif, memiliki potensi untuk mengungkapkan apa dan bagaimana realitas itu terjadi lebih baik dan dapat mendukung yang lebih diperlukan untuk meningkatkan kesejahteraan. Dalam hal ini, studi fenomenologi dengan mengambil kasus pengaitan pengentasan kemiskinan melalui pariwisata populer memprioritaskan pandangan dan perspektif untuk kesejahteraan masyarakat sebagai subjek dan pengelola pariwisata berkelanjutan.

Berdasarkan uraian latar belakang yang telah dijelaskan sebelumnya, penelitian ini bertujuan untuk (1) mengetahui perkembangan pariwisata populer di Bali; (2) untuk mengetahui program pengentasan kemiskinan Bali dan kendala-kendalanya; dan (3) untuk mengetahui kontribusi pariwisata dalam pengentasan kemiskinan. Oleh karena itu, diharapkan dapat memberikan manfaat berupa kontribusi pemikiran dan saran kepada semua pemangku kepentingan, seperti pemerintah, praktisi, dan masyarakat dalam rangka mensinergikan dan mengoptimalkan 
pelaksanaan pariwisata populer dan kontribusinya dapat membantu mempercepat pengentasan kemiskinan. di Bali.

\section{DASAR RELEVANSI PARIWISATA DAN KEMISKINAN}

Kontribusi pariwisata tidak diragukan lagi telah membantu mengentaskan kemiskinan. Ini dinyatakan secara tegas oleh Organisasi Pariwisata Dunia PBB (UNWTO) dalam Kode Etik Global bahwa:

Mengakui dimensi penting dan peran pariwisata sebagai instrumen positif menuju pengentasan kemiskinan dan peningkatan kualitas hidup bagi semua orang, potensinya untuk memberikan kontribusi bagi pembangunan ekonomi dan sosial, terutama negara-negara berkembang, dan kemunculannya sebagai kekuatan vital untuk mempromosikan pemahaman internasional, perdamaian dan kemakmuran.

Jelas sekali bahwa pariwisata adalah instrumen positif untuk mengentaskan kemiskinan yang dapat mengarah pada pembangunan ekonomi dan sosial terutama untuk negara-negara berkembang, dan sangat penting untuk menjaga keharmonisan dan kemakmuran. Ini juga mengacu pada pentingnya peran pariwisata untuk mencapai tujuan Tujuan Pembangunan Milenium (MDGs), terutama untuk empat titik target utama, termasuk: MDG 1 pengentasan kemiskinan, persamaan MDG 3 Gender, MDG 7 kelestarian lingkungan dan MDG 8 pembangunan global kemitraan. Substansi ini kemudian dituangkan kembali ke dalam bab yang paling jelas bagi kesejajaran masyarakat lokal dari bab 1, 2 dan 3, yaitu kontribusi Pariwisata untuk saling pengertian dan rasa hormat antara masyarakat dan masyarakat; Pariwisata sebagai kendaraan untuk pemenuhan individu dan kolektif; Pariwisata, merupakan faktor pembangunan berkelanjutan.

Berdasarkan pernyataan itulah kemudian dirumuskan bagaimana langkah-langkah konkret dan strategis berupa properti pariwisata yang 
efektif dan optimal dalam pengentasan kemiskinan di UNWTO tahun 2004 sebagai berikut:

a. Kegiatan pariwisata dapat masuk ke desa-desa terpencil dan daerahdaerah pinggiran, di mana sebagian besar penduduk miskin berada.

b. Kegiatan ekonomi dan bisnis pariwisata dapat diakses oleh usaha skala kecil dan menengah dengan modal terbatas dan berbagai tingkat keahlian.

c. Kegiatan pariwisata juga dapat mendorong pengembangan sektor tradisional lainnya yang miskin, seperti pertanian dan kerajinan tangan, mengolah banyak.

b. Pekerjaan pengrajin bersifat padat karya, sehingga dapat membuka berbagai peluang kerja bagi orang miskin baik formal maupun informal

c. Daerah marjinal, tempat tinggal orang miskin, mungkin kaya sumber daya pariwisata, sehingga memiliki keunggulan kompetitif dibandingkan dengan daerah lain ketika dikembangkan.

Dalam mengejar perwujudan sifat-sifat ini, perlu juga mengambil langkah-langkah yang dapat diimplementasikan untuk mewujudkan pembangunan pariwisata yang pro-masyarakat miskin oleh UNWTO tahun 2004 berikut:

a. Bekerja untuk orang miskin dalam bisnis pariwisata

b. Menyediakan barang dan jasa untuk bisnis pariwisata oleh orang miskin atau oleh perusahaan yang mempekerjakan orang miskin

c. Menjual barang dan jasa langsung kepada wisatawan oleh orang miskin (ekonomi informal)

d. Membangun dan menjalankan bisnis pariwisata oleh orang miskin, seperti usaha kecil dan menengah, atau perusahaan berdasarkan komunitas lokal (ekonomi formal) 
e. Pajak dan pungutan atas pendapatan atau keuntungan pariwisata diteruskan kepada orang miskin

f. Memberikan atau dukungan sukarela oleh bisnis pariwisata dan wisatawan

g. Investasi dalam pembangunan infrastruktur yang didorong oleh pariwisata juga harus menguntungkan masyarakat miskin di lingkungan, baik secara langsung maupun tidak langsung atau dengan mendukung sektor-sektor lain.

Mengacu pada apa yang telah dirumuskan oleh UNWTO, Indonesia juga telah meratifikasinya berdasarkan UU No. 10 tahun 2009 tentang Pariwisata, di Bab II; Pasal 4 telah secara eksplisit menjelaskan bahwa tujuan pariwisata salah satunya adalah untuk menghilangkan kemiskinan, sehingga ini dapat digunakan sebagai referensi untuk selalu memprioritaskan orang miskin.

\section{PENGEMBANGAN PARIWISATA BERBASIS MASYA- RAKAT DI BALI}

Awalnya, istilah pariwisata berbasis komunitas menjadi populer sejak tahun 2000. Bank Dunia meminta ini pada bulan Juli 2000, yang mulai mempertimbangkan bagaimana mengurangi kemiskinan melalui sektor pariwisata. Kemudian, ditemukan rumus dalam bentuk community based tourism (CBT), yang selanjutnya mengidentifikasi tiga kegiatan pariwisata yang dapat mendukung konsep CBT, yaitu wisata petualangan, wisata budaya dan ekowisata. Dengan memfokuskan akomodasi keluarga kecil yang dimiliki sehingga pariwisata dapat meningkatkan pendapatan masyarakat setempat, sambil menjaga dan melestarikan alam, seni, sosial budaya dan gaya hidup yang menjadi daya tarik utama suatu destinasi. Berikut ini diberikan penjelasan tentang pengembangan CBT di Bali dengan mengambil kasus di Jatiluwih, Munduk, Pejeng dan Pemuteran. 
Sebagai turunan dari CBT, ada model turunan dari pengembangan pariwisata dalam bentuk Desa Wisata. Salah satu Desa Wisata yang bahkan diakui UNESCO, sebagai Warisan Budaya Dunia adalah Jatiluwih. Desa yang telah ditetapkan sebagai Desa Wisata sejak 1990 menawarkan daya tarik wisata yang sangat menarik yang menampilkan teras yang indah dan alami, serta kehidupan masyarakat yang sebagian besar mata pencaharian petani memainkan peran di dalamnya. Ini seperti siklus yang selalu dipegang oleh Jatiluwih, yaitu petani mendapat penghasilan dengan bekerja di ladang sambil menjaga integritas alam agar dapat disajikan kepada wisatawan. Bahkan, berdasarkan kunjungan Dinas Pariwisata Provinsi Bali tahun 2013 kunjungan ke Jatiluwih semakin meningkat.

Menurut Rukendi (2008:41-44) tiket masuk turis yang kemudian menjadi sumber pendapatan dibagi rata berdasarkan redistribusi sebagai berikut: 30\% untuk Kantor Desa, 35\% untuk Desa Tradisional Jatiluwih dan 35\% untuk Desa Tradisional Gunung Sari. Dengan demikian, masyarakat lokal dapat mengelola pendapatan keuangan sendiri untuk kebutuhan desa, menghasilkan manajemen yang berkelanjutan. Jadi, seperti Zapata et al (2011:203-311) menunjukkan bahwa kebijakan pendukung top-down mungkin berguna untuk mendorong potensi ini untuk pertumbuhan menuju pembangunan yang lebih berkelanjutan. Secara lebih luas, ini juga berdampak baik pada penurunan penduduk miskin di Kabupaten Tabanan pada tahun 2011 hingga 2012 sebesar $13,22 \%$. Namun sayangnya, meskipun peningkatan jumlah kunjungan wisatawan secara bertahap, itu tidak menjamin penurunan tingkat kemiskinan juga, seperti yang terlihat dari kembalinya orang miskin di kabupaten Tabanan sebesar 7,14\%. Meski tidak terlalu besar, ini harus dibenahi untuk kemungkinan kebocoran dana atau distribusi pendapatan yang kurang merata, oleh karena itu model top-down ini harus tetap ditonton lagi oleh keberlanjutan pemerintah. 
Berbeda dengan yang top-down, sekarang beberapa daerah mulai terlihat berkembang sendiri dengan inisiatif untuk mengelola keunikan alam dan budaya menjadi daya tarik wisata, model ini kemudian disebut sebagai bottom-up. Berdasarkan lokakarya bertajuk IPEC (Indonesia Poverty and Empowerment Conference) 2014 telah diakui Desa yang dapat mengembangkan daerahnya sebagai objek wisata independen, antara lain: Desa Pejeng, Desa Munduk dan Desa Pemuteran. Ini juga tidak dapat dipisahkan dari para pionir dan pengusaha yang berani memadukan potensi lokal dan menyediakan akses ke pariwisata. Salah satu motivasi wisatawan untuk berwisata adalah menikmati suasana baru dan ketiga desa mampu memenuhi dengan karakteristik unik, Desa Munduk dengan pesona alamnya, Desa Pemuteran dengan terumbu karang dan Desa Pejeng dengan situs arkeologi dan pertaniannya.

Desa Munduk terletak di Kabupaten Banjar, Kabupaten Buleleng; desa ini baru dikenal di arena internasional dan dikembangkan pada 1990an, yang pertama kali dipelopori oleh Nyoman Bagiarta yang juga pemilik penginapan terbaik di Desa Munduk, Puri Lumbung Cottages. Desa, yang berjarak $60 \mathrm{~km}$ dari Denpasar, memadukan keindahan alam yang belum tersentuh oleh perkembangan industri dan globalisasi dan dikemas dalam suguhan ekowisata. Memasuki desa Munduk, wisatawan akan dikelilingi oleh perkebunan, sawah dan perbukitan yang lebih luas dari pemukiman warga negaranya. Tidak ada gedung pencakar langit, kebisingan kendaraan bermotor, apalagi polusi udara. Udara sejuk juga menambah kenyamanan wisatawan. Tempat wisata yang dapat dilakukan seperti trekking, interaksi dekat dengan penduduk setempat, belajar memasak makanan Bali, belajar menari, bermain musik tradisional, dan banyak lagi. Desa ini berkembang dengan sendirinya seiring dengan meningkatnya jumlah kedatangan wisatawan dan kesadaran masyarakat setempat untuk mendapatkan penghasilan selain bertani, dengan mengubah rumah menjadi tempat 
tinggal bagi wisatawan. Ada juga yang menggunakan seni kreativitas dalam bentuk suvenir yang dapat menghasilkan nilai ekonomi.

Ada juga desa yang belum tersentuh oleh gemerlapnya pariwisata, tetapi desa ini terletak di samping Ubud, yang sebenarnya menjadi salah satu ikon pariwisata Bali, ini adalah Desa Pejeng yang terletak di kabupaten Gianyar. Desa ini penuh dengan keunikan alam, seni dan warisan budaya berupa arkeologi yang semakin gencar mendongkrak pariwisata dan memperkenalkannya kepada wisatawan. Salah satu programnya adalah melalui pertunjukan berjudul Keajaiban Budaya Kinerja Royal Pejeng di Puri Agung Soma Negara Pejeng. Pertunjukan seperti ini rencananya akan rutin diadakan setiap bulan purnama dengan pementasan kesenian, khususnya seni tari topeng tradisional yang sesuai dengan potensi Kelurahan Pejeng. Desa ini cenderung memprioritaskan unsur budaya dan sejarah sebagai daya tariknya, yang tentunya membutuhkan partisipasi masyarakat baik dalam pemeliharaan maupun kinerjanya. Daya tarik tersebut misalnya dalam bentuk pelestarian budaya yang menyimpan arca-arca kuno seperti Pura Kebo Edan, Pura Arjuna Metapa, Candi Kelebutan, Pura Ukur-Ukuran. Ini juga memiliki tradisi yang unik, yaitu upacara perayaan atau odalan di Pura Penataran Sasih. Pada upacara ditampilkan berbagai kesenian seperti Siat Sampian (War of Janur), yang berarti gotong royong dan kebersamaan.

Objek wisata lain yang tidak kalah memesona adalah wisata bahari, berdasarkan Laporan dari WWF (World Wide Fund) tahun 2007, sekitar 80 persen pendapatan masyarakat Bali terkait dengan pariwisata, salah satunya adalah wisata bahari (Asdhiana, 2013). Ini juga menjadikan Desa Pemuteran sebagai salah satu Desa yang semakin terkenal. Berawal dari kepedulian I Gusti Agung Prana terhadap kerusakan alam yang terjadi di Pemuteran pada tahun 1990-an, yaitu hutan yang ditebangi dan terumbu karang dihancurkan oleh kegiatan penangkapan ikan yang tidak ramah 
lingkungan, tetapi jika itu bisa dikelola dengan baik maka dapat menarik banyak wisatawan. Ini adalah dasar untuk mengajak masyarakat mengelola terumbu karang, kegigihan ini sukses hingga saat ini Pemuteran berhasil meliput 2,5 hektar yang dibangun dengan teknik bio rock atau teknologi percepatan pertumbuhan terumbu karang dengan listrik. Tapi Prana mengklaim bahwa teknologi hanya pendukung, tetapi inti yang dihargai oleh para ahli ini adalah kesadaran dan partisipasi masyarakat setempat, dan inilah yang dunia ingin menginspirasi dunia. Dengan demikian, partisipasi masyarakat lokal adalah yang utama dan mutlak dalam mempromosikan pengembangan tujuan.

\section{PROGRAM PENGENTASAN KEMISKINAN PROVINSI BALI DAN HAMBATANNYA}

Indonesia selalu memiliki minat yang besar dalam penciptaan masyarakat yang adil dan makmur sebagaimana tercantum dalam paragraf keempat UUD 1945. Upaya pemerintah untuk berhasil meskipun lambat, menurut Analisis Profil Kemiskinan Nasional tahun 2013 mengungkapkan bahwa jumlah orang miskin pada tahun 2008 sekitar 34,96 juta orang mengalami penurunan sebesar 20,05\% menjadi sekitar 28,07 juta orang.

Provinsi Bali memiliki 185.200 orang miskin dengan persentase $5,34 \%$ berada di pedesaan. Berbagai upaya telah dilakukan oleh pemerintah, terutama melalui program Bali Mandara, mengurangi pengeluaran orang miskin melalui program jaminan sosial (JKBM, Beasiswa dan Korban) dan memastikan keberlanjutan bisnis miskin melalui program pemberdayaan miskin (Gerbangsadu, Simantri, Jamkrida, PNPM Perdesaan). Program pemerintah ini belum sepenuhnya berhasil, dilihat dari fluktuasi orang miskin di grafik 2.2. Berdasarkan grafik tampak bahwa ada peningkatan jumlah orang miskin, oleh karena itu lebih baik mempertimbangkan alternatif lain yang dapat mendukung dan 
mempercepat program pemerintah, seperti yang diungkapkan oleh Korten dalam Pitana (2006:127-129) bahwa:

"Dalam banyak kasus, masyarakat lokal hanya menjadi penerima pasif dari pembangunan, yang pada akhirnya menyebabkan ketergantungan yang berlebihan. Hal ini terjadi karena pemerintah cenderung mematuhi teori modernisasi klasik dengan konsep rasionalisasi dalam pengelolaan sumber daya lokal, sehingga meniadakan pengetahuan dan kemampuan masyarakat lokal".

Program pemerintah saat ini cenderung memberikan sesuatu yang bersifat amal alih-alih menerapkan bagaimana membantu masyarakat belajar untuk membantu diri sendiri keluar dari kemiskinan, atau membantu orang untuk membantu orang (Soetomo dalam Arieta, 2010:75). Lebih lanjut dijelaskan proses pemberdayaan masyarakat meliputi tahap-tahap berikut: (1) Tahapan penggalian dan penjangkauan masyarakat dengan motivasi dan proses kesadaran kelompok; (2) Tahapan pembentukan dan pemahaman organisasi tentang prinsip-prinsip dan kerjasama yang mendukung diri sendiri; (3) Tahap konsolidasi dan stabilisasi masyarakat yaitu penerapan prinsip manajemen dalam organisasi; (4) Tahap pengembangan produksi dan pemasaran adalah dengan meningkatkan bisnis dan kewirausahaan; (5) Tahap takeoff mampu mempertahankan kontinuitas grup, mampu berpartisipasi dalam upaya pengembangan (Mualifaf dalam Arieta, 2010).

\section{KONTRIBUSI PARIWISATA DALAM PENGENTASAN KEMISKINAN}

Pariwisata massal seakan masih prima dona dan fokus utama dari beberapa pelaku pariwisata, tak heran banyak media yang lebih bangga dengan jumlah kunjungan yang fantastis daripada peduli dengan bagaimana dampak serbuan wisatawan ini. Prinsip inilah yang kemudian 
semakin mendesak masyarakat lokal untuk terpinggirkan dan hanya menjadi pendukung, bahkan keparahan penonton kemewahan pariwisata semakin berkembang saat ini. Pertanian yang dulunya karakter utama, sekarang hanya ekstra enggan melirik, dan itu menciptakan kebocoran dana. Dengan cepat menyadari pentingnya sinergi dari dua aktor ini, yaitu melalui konsep yang berjudul CBT yang mempromosikan partisipasi masyarakat lokal untuk mengembangkan pariwisata.

Dengan mengambil pariwisata populer, lihat dari jumlah orang miskin yang sebagian besar berada di daerah pedesaan. Berdasarkan data Bali BPS bahwa pada Maret 2014 ada 85.300 orang miskin di daerah pedesaan, yang meningkat $5,34 \%$. Jika dibandingkan dengan penduduk perkotaan yang hanya meningkat sebesar $4,01 \%$. Juga disebutkan bahwa berdasarkan Data Bangunan Bali tahun 2013 meskipun sektor pertanian dalam arti luas menempati posisi teratas sebagai mata pencaharian, tetapi telah menurun secara bertahap dan digantikan dengan posisi pariwisata, dalam hal ini sektor Perdagangan, Restoran dan Layanan Akomodasi.

Bahkan, menurut Biro Pusat Statistik Bali, meskipun pertumbuhan ekonomi Bali mencapai 6,7\%, tercatat bahwa penduduk miskin pada Maret 2014 adalah 185.200 orang atau meningkat 0,04\% dibandingkan dengan data September 2013. September 2013, jumlah penduduk miskin perkotaan mengalami penurunan sebesar 3,1\% sementara penduduk miskin pedesaan meningkat sebesar 6,5\%. Ketimpangan distribusi pendapatan masyarakat Bali berada dalam kategori sedang, dilihat dari Rasio Gini di 0,403 pada tahun 2013, lebih baik dari tahun sebelumnya yaitu 0,43. Akhirnya, meskipun kemiskinan adalah masalah kompleks yang tidak dapat diselesaikan dengan satu cara, setidaknya kita masih dapat mengandalkan pariwisata, mengutip dari Zapata dkk (2013):

"Kemiskinan adalah salah satu masalah meta kemanusiaan yang tidak ada jawaban atau solusi unik. Berbagai tindakan diperlukan untuk 
memberantas kemiskinan dan, dalam keadaan tertentu seperti yang telah disimpulkan di atas, CBT dapat memberikan kontribusi”.

\section{KESIMPULAN DAN SARAN}

Kontribusi pariwisata memang telah diakui secara internasional, karena UNWTO mengungkapkan bahwa pariwisata menyumbang 9\% dari total PDB, 1 dari 11 pekerjaan di seluruh dunia dan merupakan kunci bagi pembangunan ekonomi. Bahkan, pariwisata memiliki dampak yang luar biasa pada sosio-budaya, lingkungan dan ekonomi. Ironisnya, masih ada paradoks, terutama antara pariwisata dan kondisi ekonomi, pariwisata harus dibarengi dengan kesejahteraan rakyat, tetapi masih terlihat peningkatan jumlah penduduk miskin. Program pengentasan kemiskinan Pemerintah saat ini tidak terlalu efektif dengan fokus utama bantuan materi, sedangkan yang paling penting adalah pendidikan dan pembelajaran sehingga masyarakat dapat menyelamatkan diri sendiri untuk keluar dari siklus kemiskinan.

Inilah alasan utama munculnya konsep pariwisata kerakyatan dengan memusatkan perhatian pada bagaimana masyarakat itu sendiri menjadi subjek pariwisata. Pijakan dasar adalah bahwa penduduk lokal yang lebih tahu tentang wilayah dan melalui pariwisata populer dapat memperoleh penghasilan langsung dan mengurangi kebocoran dana, serta inisiatif untuk lebih melestarikan kondisi lingkungan dan budaya yang merupakan aset penting dari objek wisata. Dengan demikian, pariwisata yang pernah dituduh menyebabkan disparitas pendapatan dan meminggirkan masyarakat lokal kini ditolak oleh kehadiran pariwisata populer yang sebenarnya bertindak sebagai akselerator pengentasan kemiskinan.

Ada beberapa contoh pariwisata populer yang telah menuai dampak positif, seperti Desa Jatiluwih, Pejeng, Munduk dan Pemuteran. 
Ini juga harus digunakan sebagai contoh untuk desa lain, dari bagaimana mengelola, memasarkan produk dan distribusi pendapat melalui sinergi dan kerja sama antara pelaku pariwisata, pemerintah dan adat istiadat. Selain itu, pemerintah juga harus mengawasi penerapan CBT dengan model top-down dan merangsang area lain, terutama yang belum tersentuh oleh pariwisata, untuk mengembangkan model bottom-up. Jadi pariwisata berkorelasi positif dengan kesejahteraan masyarakat.

\section{DAFTAR PUSTAKA}

Amiani, Nyoman Dini. 2008. Pengembangan Ekowisata yang Berbasis Masyarakat Menuju Pariwisata Berkelanjutan di Kelurahan Serangan, Bali. Jurnal Kepariwisataan Indonesia, Vo.3, No.2, hal. 331-339. Jakarta: Pusat Penelitian dan Pengembangan Kepariwisataan

Arieta, Siti. 2010. Community Based Tourism Pada Masyarakat Pesisir: Dampaknya Terhadap Lingkungan dan Pemberdayaan Ekonomi. Jurnal Dinamika Maritim, Vol.2, No.1. Tersedia di http://riset.umrah.ac.id/

Asdhiana, I Made. 2013. "Lingkungan Pulih, Potensi Bali Membesar". Tersedia di: http://www.balipost.co.id/

Badan Pusat Statistik Bali. 2013. Distribusi Pendapatan Provinsi Bali Menurut Kabupaten/Kota Tahun 2013. Tersedia di http://bali.bps.go.id

Badan Pusat Statistik Provinsi Bali. 2014. “Jumlah Penduduk Miskin di Bali”. Tersedia di http://bali.bps.go.id

Budhi, Made Kembar Sri. 2013. Analisis Faktor-faktor yang Berpengaruh Terhadap Pengentasan Kemiskinan di Bali: Analisis FEM Data Panel. Jurnal Ekonomi Kuantitatif Terapan, Vol. 6, No. 1, hal. 16. Tersedia di: ojs.unud.ac.id

Dinas Pariwisata Provinsi Bali. 2013. Statistik Pariwisata Bali. Denpasar: Dinas Pariwisata Provinsi Bali

Dinas Pariwisata Provinsi Bali. 2014. Jumlah Kunjungan Wisatawan ke Jatiluwih. Tersedia di: www.disparda.baliprov.go.id

Kementrian Sosial Republik Indonesia. 2014. Analisis Profil Kemiskinan Nasional. Tersedia di: www.slideshare.net

Pemerintah Provinsi Bali Badan Perencanaan Pembangunan Daerah. 2014. Data Bali Membangun 2013. Denpasar: Badan Perencanaan Pembangunan Daerah 
Pitana, I Gde. 2002. Apresiasi Kritis Terhadap Kepariwisataan Bali. Denpasar: PT The Works

Pitana, I Gde. 2006. Kepariwisataan Bali dalam Wacana Otonomi Daerah. Jakarta: Puslitbang Kepariwisataan

Rukendi, Cecep dkk. 2008. Menanggulangi Kemiskinan Melalui Agrowisata dan Wisata Perdesaan yang Berkelanjutan. Jurnal Kepariwisataan Indonesia, Vo.3, No.4, hal. 503-510. Jakarta: Pusat Penelitian dan Pengembangan Kepariwisataan

Schutz, Alfred, 1967, The Phenomenology of the Social World. Evanston: Illinois Northwestern University Press.

UNWTO. 2001. Global Code of Ethics. Tersedia di: www.unwto.org UNWTO. 2004. Indicators of Sustainable Development for Tourism Destinations: A Guide Book. Madrid, Spain: WTO

UU No. 10 Tahun 2009 tentang Kepariwisataan

Zapata, M.J et al. 2011. Can Community-based Tourism Contribute to Development and Poverty Alleviation? Lessons from Nicaragua. Current Issues in Tourism, Vol. 01, No. 1, pg. 1-25. Tersedia di https://www.academia.edu/ 
Putu Devi Rosalina

72 JOURNEY Volume 1 Nomor 1 Desember 2018 